\title{
JOD-BASEDOW PHENOMENON: PHENOMENAL THYROTOXICOSIS?
}

\author{
Ozturk Tuncer, ${ }^{1}$ Sengul Demet, ${ }^{2}$ Sengul Ilker ${ }^{1,3}$ \\ ${ }^{1}$ Department of General Surgery, Giresun University Faculty of Medicine, Giresun, Turkey \\ ${ }^{2}$ Department of Pathology, Giresun University Faculty of Medicine, Giresun, Turkey \\ ${ }^{3}$ Division of Endocrine Surgery, Giresun University Faculty of Medicine, Giresun, Turkey
}

Primljen/Received 01. 12. 2021. god.

Abstract: A Deucalione iodine is an essential mineral vital for the optimal function of the thyroid gland in human beings. Apart from being found in a variety of foods, it is a component of various medications, amiodarone and expectorants, iodine-based swabs used for skin cleaning before interventional and surgical procedures, and iodinated contrast media in medical settings. Jod-Basedow Phenomenon, also known as Jod-Basedow Syndrome or iodine-induced thyrotoxicosis, is a rare cause of thyrotoxicosis that characteristically refers to a paradoxical phenomenon in which large loads of exogenous iodine can cause hyperthyroidism. This phenomenon is mainly seen in populations already at risk for thyroid diseases, such as autoimmune thyroid diseases, prior thyroid surgical history, latent Graves' disease, and prior non-toxic diffuse or nodular goiter formation, or those with underlying kidney disease, such as chronic kidney disease and end-stage renal disorders, which can impact iodine excretion. Typically, it is recognized in those with the administration of a large iodine load, dietary supplement, iodinated contrast media used in conjunction with computed tomography scans, angiography, and various other imaging studies, iodinated antiseptic solutions and oral supplements, or a medication, mainly amiodarone, class III antiarrhythmic drug used in the treatment of recurrent severe ventricular arrhythmias, paroxysmal atrial tachycardia, atrial fibrillation and maintenance of sinus rhythm after cardioversion of atrial fibrillation. Prophylactic medical management of the phenomenon may include antithyroid drugs, methimazole, or perchlorate, to be considered for patients at risk for developing iodine-induced thyrotoxicosis that is scheduled for imaging modalities by using iodinated contrast media. Moreover, the preliminary management modality comprises cessation of iodine administration, avoiding further exposure, administration of beta-adrenergic antagonists, thionamides, cor-
Prihvaćen/Accepted 22. 12. 2021. god.

ticosteroids, and rarely lithium. Prognosis is usually favorable, although a small percentage of cases could suffer permanent sequelae from iodine-induced thyrotoxicosis. Nevertheless, complications are remarkable including thyroid storm, permanent hyperthyroidism, atrial fibrillation, and fetal hypothyroidism with goiter development, in terms of ordering iodinated contrast media in pregnants. Jod-Basedow Phenomenon should not be overlooked and should be managed by an interprofessional healthcare team serving and officiating not only to treat it but also to concern themselves, actively in the relevant prophylaxis.

Key words: Jod-Basedow Phenomenon, Jod-Basedow Syndrome, Iodine-induced thyroidoxicosis, Thyrotoxicosis, Thyroid gland, Thyroidology, Iodine, Graves' Disease, Goiter, Pathology, Endocrine Surgery.

\section{INTRODUCTION}

The Jod-Basedow Phenomenon comes from "Jod", meaning iodine in German, and the German scientist Karl Adolph von Basedow (1799-1854). Jod-Basedow Syndrome has diverged from Basedow's disease, occasionally used as a synonym for Graves' disease. Jod-Basedow effect, the so-called Jod-Basedow Syndrome, and Jod-Basedow Phenomenon is a kind of thyrotoxicosis following administration of iodine or iodide through a dietary supplement, iodinated contrast medical imaging, or a medication, mainly amiodarone. Iodine, a member of group 17 in the periodic table, is the fourth halogen, below fluorine, chlorine, and bromine. Iodine is the heaviest stable member of its group and has an electron configuration of $[\mathrm{Kr}] 4 \mathrm{~d} 105 \mathrm{~s} 25 \mathrm{p} 5$ with the seven electrons in the fifth and outermost shell as its valence electrons and atomic weight $126,90447 \mathrm{u}$. Iodine is crucial for the regular functioning of the most important endocrine gland, the thyroid. The human body would not carry on to syn- 
thesize the vital hormones for maintaining metabolic homeostasis of homo sapiens: the thyroid hormones, T3 and T4. On the other side, excess iodide, such as iodinated contrast media (ICM) administration, may impact the normal functioning thyroid gland $(1,2)$.

\section{JOD-BASEDOW PHENOMENON}

\section{Iodine Sources}

Iodine can be obtained by consuming foods that contain it. Dietary iodine is absorbed from the stomach and duodenum at the rate of $>90 \%$ as iodide and is rapidly distributed in the extracellular fluid. It is also transported to the papillon-shaped gland by sodium/ iodide symporter (NIS) with a considerable gradient of 25-50 times of plasma content. Iodide leaves this pool by being transported to the thyroid and excreted in the urine. The minimum recommended daily intake of iodine is $150 \mu \mathrm{g}$ for non-pregnant adults, 220-250 $\mu \mathrm{g}$ for pregnant women, $290 \mu \mathrm{g}$ for lactating, and 90-120 $\mu \mathrm{g}$ for children $(2,3)$.

\section{Etiology}

Jod-Basedow Phenomenon scarcely arises in the absence of an underlying thyroid gland disease, such as autoimmune thyroid diseases, iodine-induced thyroiditis, previous thyroid surgical procedures, latent Graves' disease, and nontoxic diffuse or nodular goiter, or underlying kidney disease, such as chronic kidney disease and end-stage renal disorders, which can impact iodine excretion, all which are considered as its predisposing factors. Patients at risk are elderly and those from low iodine intake topographic areas. In addition, chronic and end-stage renal diseases are also known as the risk factors for the phenomenon as iodine is excreted through the kidneys. It is also worth noting that Jod-Basedow Phenomenon is interrelated with ICM. Moreover, other exogenous sources such as oral supplements and iodinated antiseptic solutions may also lead to iodine-induced thyrotoxicosis. Furthermore, amiodarone-induced thyrotoxicosis (AIT), which is classified as type I, AIT 1; which may develop in the presence of latent autoimmune hyperthyroid status (routinely requires treatment with thionamides) and type II, AIT 2; which develops in a normal thyroid status resulting from destructive thyroiditis (requires steroids), is accepted as a separate entity and its underlying mechanism may be different from the other counterparts $(2,4)$.

\section{Epidemiology}

Jod-Basedow Phenomenon has been revealed as a rare situation with just a small collection of reports determining its features as if it has been under-reported. Physicians may consider that diagnostic contingency with increased awareness in terms of this entity $(1,2,3)$.

\section{Pathophysiology}

Jod-Basedow Syndrome, iodine-induced thyrotoxicosis, typically occurs in a case with an endemic goiter due to iodine deficiency who has later been relocated to an iodine-abundant topographic area. Risky individuals for the Jod-Basedow effect include the ones with Graves' disease, toxic multinodular goiter, and thyroid adenoma while taking iodine due to the thyroid gland then not responding to negative feedback from increased thyroid hormones. Hyperthyroidism frequently emerges within 2 to 12 weeks following iodine administration which may involve diet, administration of ICM for medical imaging, or an antiarrhythmic drug, so-called amiodarone. Intercalary, excess iodide load may impact this crucial endocrine gland functioning. In this case, a transient attenuation in thyroid hormone production is the expected initial response. This phenomenon, the WolffChaikoff effect, is predicted as an output of a temporary downregulation of the sodium iodide transporter in the thyroid. Most cases can provide a euthyroid state in their organism within 24 to 48 hours, whereas some exhibit the opposite response for the mentioned condition. By escaping the physiologic negative feedback mechanism of the Wolff-Chaikoff effect they evolve the hyperthyroid status instead of a transitory hypothyroid hormonal state. Last but not least, the mentioned pathologic response to the exogenously administered iodine charge is described as the Jod-Basedow Phenomenon which is thought to emerge from an output of impaired autoregulation $(1,2,5,6)$. The key factor protecting organisms against wide variations in dietary iodine intake is described as autoregulation by thyroid follicular cells. Sudden exposure to excess serum iodide inhibits iodide organification, thereby reducing hormone biosynthesis, and this phenomenon is called the Wolff-Chaikoff effect $(2,5,6)$. However, iodide overload, iodide organization, and thyroid hormone biosynthesis continue normally two to four weeks after ongoing exposure (7). Experimental studies have propounded and suggested that this escape from the Wolff-Chaikoff effect is due to the attenuation of iodide uptake, thus getting back of the intrathyroidal iodide pool to its normal available value even if serum concentrations of iodide remain high (8-10). The mechanism of this escape is unknown but may be related, in part, to a decrease in iodide uptake caused by a downregulation in NIS activity for the thyroid. This phenomenal thyrotoxicosis appears to result from loss 
of the normal adaptation of the gland to iodide overcharge $(11,12)$.

\section{Iodine-effects on thyroid hormone secretion}

The pharmacological doses of iodine attenuate thyroglobulin proteolysis by reducing thyroid hormone secretion by using its most rapid effects. A transient augmentation in serum concentrations of thyroid-stimulating hormone (TSH) occurs through a mild decrease in serum T4 and T3 hormones (13-15). Serum TSH augmentation may not be present in the presence of increased iodine intake in the elderly (16). The effects of iodine charge in cases with abnormal thyroids are different from those in normal individuals. It depends on the underlying disease process, e.g. iodine administration may lead to thyrotoxicosis in cases with nodular goiter involving autonomously functioning parenchyma or with endemic goiter. A high incidence, $10-20 \%$, of thyrotoxicosis is revealed in people with nodular goiter living in iodine-deficient areas while a lower prevalence of hyperthyroidism, $1-20 \%$, has been expressed after the iodine introduction $(17,18)$. Autonomous areas within the gland may lead to hyperthyroidism, exempli gratia, increasing iodine supply, producing thyroid hormones in autonomous areas independently of normal regulatory mechanisms: Jod-Basedow Phenomenon (19). Jod-Basedow Syndrome may scarcely appear in cases without underlying a thyroid disease such as iodine-induced thyroiditis (20).

\section{Diagnosis}

Diagnosis of Jod-Basedow Phenomenon may be achieved concerning nodular diseases on physical examination, particularly in cases with iodine exposure like coronary angiography and imaging contrast media and clinical manifestations of thyrotoxicosis, such as tachycardia, tremor, heat intolerance, restlessness, diarrhea, and insomnia. Besides this phenomenon, severe cases may lead to thyroid storm, characteristically exhibiting a constellation of symptoms including tachycardia, diarrhea, fever, altered levels of consciousness, even development of atrial fibrillation in rare cases. Diagnosis should be confirmed by the hormonal status of the thyroid gland. Jod-Basedow Syndrome characteristically initiates weeks or even months after an initial iodine administration $(21,22)$.

\section{Evaluation of underlying thyroid disease}

Even though the phenomenon most frequently occurs in patients with underlying thyroid disease, other causes of thyrotoxicosis should be considered, as it may not be associated with iodine exposure. Besides the physical examination, multinodular gland suggestive of thyroid autonomy, diffuse goiter suggestive of Graves' disease, ophthalmopathy, dermatopathy, the biochemical, thyroid-stimulating immunoglobulin (TSI) level, and radiologic imaging, radioactive iodine uptake, thyroid nodularity in sonography, and vascularity in doppler ultrasound, tests may be beneficial for the diagnostic purposes even in the differential diagnosis (2).

\section{Prognosis}

As a result of prolonged iodine deficiency, thyrocyte proliferation and mutation rates increase leading to multifocal autonomous growth. Thyrocytes that change in this way form cell clones in the thyroid parenchyma which results in mutations in TSH receptors. This fine nodular pattern exhibits autonomy within the gland following iodine intake and rapidly synthesizes thyroid hormones inducing a hyperthyroid hormonal status in human beings. In fine, it is obvious to expect possessing hyperthyroidism through administration of iodine in already autonomous glands in individuals with long-term iodine deficiency (23-25).

The prognosis for the Jod-Basedow Phenomenon is usually affirmative. Iodine-induced thyrotoxicosis is ordinarily self-limited with a time interval of 1-18 months subject to the condition, cessation of iodine repletion, while delay in recovery may exist in amiodarone-induced thyrotoxicosis. Though a small percentage of cases may have difficulty in a persistent sequela, most patients return to their baseline hormonal status of the thyroid $(2,3,26,27)$.

\section{Management}

Prophylactic medical management may involve antithyroid drugs, methimazole, or perchlorate, to be considered for cases at risk for developing iodine-induced thyrotoxicosis that is scheduled for imaging modalities by using ICM. The preliminary management modality for patients with Jod-Basedow Phenomenon includes discontinuation of iodine administration, avoiding further exposure, and administration of a beta-adrenergic antagonist, like atenolol $25-50 \mathrm{mg} /$ day, as an initial dose, to alleviate the symptoms of thyrotoxicosis (27). The thyroid hormonal status should be followed up considering its baseline levels, individually. Beta-blockers can be reduced and discontinued after thyroid tests return to normal. Thionamide administration may accelerate the recovery (20). Methimazole with a starting dose once daily 10 to $20 \mathrm{mg}$, due to long duration of action, faster efficacy, and lower incidence of side effects, can be used in case of severe or prolonged, > 1 month, symptoms of hyperthyroid- 
ism or elderly with underlying cardiovascular disease. Inter alia, corticosteroid therapy is recommended to expedite the return of the gland hormones to their normal ranges. Corticosteroids were asserted as might delay or circumvent surgical management thus refraining from its possible complications. Providers may regard to prescribe lithium by virtue of inhibitory impacts on the thyroid gland under the circumstances of the antithyroid drugs failing to reduce thyroid hormone production $(2,26,28-36)$.

\section{CONCLUSION}

Iodine is an essential mineral vital for the optimal function of the thyroid gland in human beings. Apart from being found in a variety of foods, it is a component of various medications, amiodarone and expectorants, iodine-based swabs used for skin cleaning prior to interventional and surgical procedures, and iodinated contrast media, in medical settings. A Deucalione, this delicate and crucial endocrine gland, remains its great emphasis on a human being. However, the debate is still ongoing, particularly, in remarkable controversial issues in Thyroidology, to date.

Jod-Basedow Phenomenon, so-called Jod-Basedow Syndrome or iodine-induced thyrotoxicosis, is a seldom cause of thyrotoxicosis of a paradoxical phenomenon in which large loads of exogenous iodine can be a causative agent. Prior settlement in an iodine-deficient area, possessing an underlying thyroid or kidney disease with the administration of a large iodine load are the prominent features. The phenomenon is ordinarily self-limited though a small percentage of cases may have difficulty in a persistent sequela. Nevertheless, complications of the Jod-Basedow Phenomenon are remarkable. As well as prophylactic medical management, the preliminary management modality with cessation of the causative agent, avoiding further exposure, administration of beta-adrenergic antagonists, thionamides, corticosteroids, and even rarely lithium is referred to. Jod-Basedow Phenomenon should not be overlooked or be managed by an interprofessional healthcare team serving and officiating not only to treat it, but also regarding relevant prophylaxis. Bene diagnoscitur, bene curatur.

Acknowledgments: None

Conflict of Interests: The authors declare that there are no conflicts of interest related to this article.

Funding: None

\section{Licensing}

This work is licensed under a Creative Commons Attribution 4.0 International (CC BY 4.0) License

\title{
Sažetak
}

\section{JOD-BASEDOW FENOMEN: FENOMENALNA TIROTOKSIKOZA?}

\author{
Ozturk Tuncer, ${ }^{1}$ Sengul Demet, ${ }^{2}$ Sengul Ilker ${ }^{1,3}$ \\ ${ }^{1}$ Department of General Surgery, Giresun University Faculty of Medicine, Giresun, Turkey \\ ${ }^{2}$ Department of Pathology, Giresun University Faculty of Medicine, Giresun, Turkey \\ ${ }^{3}$ Division of Endocrine Surgery, Giresun University Faculty of Medicine, Giresun, Turkey
}

Deukalion jod je esencijalni mineral od vitalnog značaja za optimalno funkcionisanje štitne žlezde kod ljudi. Osim što se nalazi u raznim namirnicama, sastavni je deo raznih lekova, amiodarona i ekspektoransa, sredstava na bazi joda koji se koriste za čišćenje kože pre intervencijskih i hirurških zahvata, $\mathrm{i}$ jodiranih kontrastnih sredstava u medicinskim ustanovama. Jod-Basedov fenomen, takođe poznat kao Jod-Basedov sindrom ili tireotoksikoza izazvana jodom, je redak uzrok tireotoksikoze koji se karakteristično odnosi na paradoksalan fenomen u kojem velika opterećenja egzogenog joda mogu izazvati hipertireozu. Ovaj fenomen se uglavnom primećuje kod populacije koja je već izložena riziku od oboljenja štitne žlezde, kao što su autoimune bolesti štitne žlezde, prethodna istorija hirurške intervencije na štitnoj žlezdi, latentna Grejvsova bolest i prethodno formiranje netoksične difuzne ili nodularne strume, ili kod onih sa osnovnom bolešću bubrega, kao npr. hronična bolest bubrega i bubrežni poremećaji u završnoj fazi, koji mogu uticati na izlučivanje joda. Obično se prepoznaje kod onih sa velikim opterećenjem jodom, dijetetskim suplementima, jodnim kontrastnim sredstvima koji se koriste kod kompjuterizovane tomografije, angiografije i u raznim drugim imidžing studijama, jodiranim antiseptičkim rastvorima i oralnim suplementima ili lekovima, uglavnom amiodaron, antiaritmik koji se koristi u lečenju ponavljajućih teških ventrikularnih aritmija, paroksizmalne atrijalne tahikardije, atrijalne fibrilacije i održavanja sinusnog ritma nakon kardioverzije atrijalne fibrilacije. Profilaktički medicinski tretman ovog fenomena može uključivati lekove protiv štitne žlezde, metimazol ili perhlorat, koji se razmatraju za pacijente sa rizikom od razvoja tireotoksikoze izazvane jodom, koja je predviđena za modalitete radio-snimanja 
korišćenjem jodiranih kontrastnih sredstava. Štaviše, preliminarni modalitet lečenja uključuje prestanak primene joda, izbegavanje daljeg izlaganja, primenu beta-adrenergičkih antagonista, tionamida, kortikosteroida i retko litijuma. Prognoza je obično povoljna, iako bi mali procenat slučajeva mogao imati trajne posledice od tireotoksikoze izazvane jodom. Ipak, komplikacije su velike, uključujući štitnu žlezdu, trajnu hipertireozu, atrijalnu fibrilaciju i fetalnu hipotireozu sa razvo-

\section{REFERENCES}

1. El-Shirbiny AM, Stavrou SS, Dnistrian A, Sonenberg M, Larson SM, Divgi CR. Jod-Basedow syndrome following oral administration of iodine and radioiodinated antibodies. $\mathrm{J}$ Nucl Med. 1997; 38(11): 1816-7.

2. Rose HR, Zulfiqar H. Jod Basedow Syndrome. In: StatPearls. StatPearls Publishing, Treasure Island (FL); 2021.

3. Sengul I, Sengul D, Pelikán A. Iodine-induced hyperthyroidism: Do you mind? Sanamed. 2020; 15(2): 215-7. doi 10.24125/sanamed.v15i2.458.

4. Andreucci M, Solomon R, Tasanarong A. Side effects of radiographic contrast media: pathogenesis, risk factors, and prevention. Biomed Res Int. 2014; 2014: 741018. doi: 10.1155/2014/741018.

5. Lee SY, Rhee CM, Leung AM, Braverman LE, Brent GA, Pearce EN. A review: Radiographic iodinated contrast media-induced thyroid dysfunction. J Clin Endocrinol Metab. 2015; 100(2): 376-83. doi: 10.1210/jc.2014-3292.

6. Wolf J, Chaikoff IL. Plasma inorganic iodide as a homeostatic regulator of thyroid function. J Biol Chem. 1948; 174(2): 555-64.

7. Galton VA, Pitt-Rivers R. The effect of excessive iodine on the thyroid of the rat. Endocrinology. 1959; 64(5): 8359. doi: 10.1210/endo-64-5-835.

8. Nagataki S, Ingbar SH. Relation between qualitative and quantitative alterations in thyroid hormone synthesis induced by varying doses of iodide. Endocrinology. 1964; 74: 731-6. doi: 10.1210/endo-74-5-731.

9. Dai G, Levy O, Carrasco N. Cloning and characterization of the thyroid iodide transporter. Nature. 1996; 379(6564): 458-60. doi: 10.1038/379458a0.

10. Eng PH, Cardona GR, Fang SL, Previti M, Alex S, Carrasco N, et al. Escape from the acute Wolff-Chaikoff effect is associated with a decrease in thyroid sodium/iodide symporter messenger ribonucleic acid and protein. Endocrinology. 1999; 140(8): 3404-10. doi: 10.1210/endo.140.8.6893.

11. Saberi M, Utiger RD. Augmentation of thyrotropin responses to thyrotropin-releasing hormone following small decreases in serum thyroid hormone concentrations. J Clin Endocrinol Metab. 1975; 40(3): 435-41. doi: 10.1210/jcem-40-3-435.

12. Markou KB, Paraskevopoulou P, Karaiskos KS, Makri M, Georgopoulos NA, Iconomou G, et al. Hyperthyrotropinemia during iodide administration in normal children and in children born with neonatal transient hypothyroidism. J Clin Endocrinol Metab. 2003; 88(2): 617-21. doi: 10.1210/jc.2002020681 .

13. Braverman LE. Iodine and the thyroid: 33 years of study. Thyroid. 1994; 4(3): 351-6. doi: 10.1089/thy.1994.4.351. jem strume, u smislu korišćenja jodiranih kontrastnih sredstava kod trudnica. Jod-Basedov fenomen ne treba zanemariti i njime treba upravljati interprofesionalni zdravstveni tim koji služi ne samo da ga leči već i da se brine aktivno u relevantnoj profilaksi.

Ključne reči: Jod-Basedov fenomen, Jod-Basedov sindrom, tireotoksikoza izazvana jodom, tireotoksikoza, štitna žlezda, tiroidologija, jod, Grejvsova bolest, struma, patologija, endokrina hirurgija.

14. Gartner W, Weissel M. Do iodine-containing contrast media induce clinically relevant changes in thyroid function parameters of euthyroid patients within the first week? Thyroid. 2004; 14(7): 521-4. doi: 10.1089/1050725041517075.

15. Ordene KW, Pan C, Barzel US, Surks MI. Variable thyrotropin response to thyrotropin-releasing hormone after small decreases in plasma thyroid hormone concentrations in patients of advanced age. Metabolism. 1983; 32(9): 881-8. doi: 10.1016/0026-0495(83)90201-9.

16. Roti E, Uberti ED. Iodine excess and hyperthyroidism. Thyroid. 2001; 11(5): 493-500. doi: 10.1089/ 105072501300176453.

17. Stanbury JB, Ermans AE, Bourdoux P, Todd C, Oken E, Tonglet R, et al. Iodine-induced hyperthyroidism: occurrence and epidemiology. Thyroid. 1998; 8(1): 83-100. doi: 10.1089/ thy.1998.8.83.

18. Skare S, Frey HM. Iodine induced thyrotoxicosis in apparently normal thyroid glands. Acta Endocrinol (Copenh). 1980; 94(3): 332-6. doi: 10.1530/acta.0.0940332.

19. Fricke E, Fricke H, Esdorn E, Kammeier A, Lindner $\mathrm{O}$, Kleesiek K, et al. Scintigraphy for risk stratification of iodine-induced thyrotoxicosis in patients receiving contrast agent for coronary angiography: a prospective study of patients with low thyrotropin. J Clin Endocrinol Metab. 2004; 89(12): 60926. doi: 10.1210/jc.2004-0728.

20. Burman KD, Wartofsky L. Iodine effects on the thyroid gland: biochemical and clinical aspects. Rev Endocr Metab Disord. 2000; 1(1-2): 19-25. doi: 10.1023/a:1010004218052.

21. Higgs M, Hull E, Lujan E. A case report of post-operative Jöd-Basedow Phenomenon following oral and iv iodine contrast administration. Case Rep Endocrinol. 2014; 2014: 980283. doi: 10.1155/2014/980283.

22. Adler J, Colegrove DJ. Contrast-induced thyrotoxicosis in a patient with new-onset atrial fibrillation: a case report and review. J Atr Fibrillation. 2013; 6(1): 379. doi: 10.4022/ jafib.379.

23. Azizi F, Daftarian N. Side-effects of iodized oil administration in patients with simple goiter. J Endocrinol Invest. 2001; 24(2): 72-7. doi: 10.1007/BF03343816.

24. Tonacchera M, Agretti P, Chiovato L, Rosellini V, Ceccarini G, Perri A, et al. Activating thyrotropin receptor mutations are present in non adenomatous hyperfunctioning nodules of toxic or autonomous multinodular goiter. J Clin Endocrinol Metab. 2000; 85(6): 2270-4. doi: 10.1210/jcem.85.6.6634.

25. Mirmiran P, Kimiagar M, Azizi F. Three-year survey of effects of iodized oil injection in schoolchildren with iodine deficiency disorders. Exp Clin Endocrinol Diabetes. 2002; 110(8): 393-7. doi: 10.1055/s-2002-36425. 
26. Henry RK,Chaudhari M. In iodine-induced thyrotoxicosis, steroid therapy today could keep the surgical knife at bay. J Pediatr Endocrinol Metab. 2018; 31(5): 585-8. doi: 10.1515/ jpem-2017-0485.

27. Martino E, Bartalena L, Bogazzi F, Braverman LE. The effects of amiodarone on the thyroid. Endocr Rev. 2001; 22(2): 240-54. doi: 10.1210/edrv.22.2.0427.

28. Sengul I, Sengul D. Delicate needle with the finest gauge for a butterfly gland, the thyroid: Is it worth mentioning? Sanamed. 2021; 16(2): 173-4. doi: 10.24125/sanamed. v16i2.515.

29. Sengul D, Sengul I, Pelikán A. Paraphrase for the impact of repeat fine-needle aspiration in thyroid nodules categorized as atypia of undetermined significance or follicular lesion of undetermined significance: A single-center experience. Diagn Cytopathol. 2021; 49(3): 452-3. doi: 10.1002/dc.24685.

30. Sengul I, Sengul D. Focusing on thyroid nodules in suspense: $10-15 \mathrm{~mm}$ with repeat cytology, Category III, the Bethesda System for Reporting Thyroid Cytopathology, TBSRTC. Rev Assoc Med Bras (1992). 2021; 67(2): 166-7. doi 10.1590/1806-9282.67.02.20200828.

31. Sengul D, Sengul I, Van Slycke S. Risk stratification of the thyroid nodule with Bethesda indeterminate cytology, category III, IV, V on the one surgeon-performed US-guided fine-needle aspiration with a 27 -gauge needle, verified by histopathology of thyroidectomy: the additional value of one surgeon-performed elastography. Acta Chir Belg. 2019; 119(1): 38-46. doi: 10.1080/00015458.2018.1551769.

32. Sengul I, Sengul D. Blurred lines for management of thyroid nodules in the era of AUS/FLUS: Novel subdivisions of Category IIIA and IIIB in a possible forthcoming TBSRTC, 3rd ed.; amending vs. unnecessary? Rev Assoc Med Bras (1992). 2021; 67(10): 1385-6. doi: 10.1590/1806-9282.20210763.

33. Sengul D, Sengul I. A closer look at the size cutoff of $10 \mathrm{~mm}$, under $10 \mathrm{~mm}$ in particular, in Thyroidology: Debate is still ongoing. Rev Assoc Med Bras (1992). 2021; 67(11): 15234. doi: 10.1590/1806-9282.20210856.

34. Sengul D, Sengul I. Reassessing combining real-time elastography with fine-needle aspiration biopsy to identify malignant thyroid nodules. Am J Med Case Rep. 2021; 9(11): 5523. doi: 10.12691/ajmcr-9-11-9.

35. Sengul D, Sengul I. Comments: Effect of the location and size of thyroid nodules on the diagnostic performance of ultrasound elastography: A retrospective analysis. Clinics (São Paulo). 2021; 76: e2891. doi: 10.6061/clinics/2021/e2891.

36. Sengul I, Sengul D. Notes on "elastography for the diagnosis of high-suspicion thyroid nodules based on the 2015 American Thyroid Association guidelines: a multicenter study". North Clin Istanb. 2021; 8(1): 109-10. doi: 10.14744/ nci.2020.74240

\section{Correspondence to/Autor za korespondenciju}

Prof (Assoc) Demet Sengul, M.D.

Founder Chair, Department of Pathology

Founder Chair, Scientific and Research Laboratories

Giresun University Faculty of Medicine

Gazipasa Compound, Gazi Avenue, Giresun, Turkey

E-mail: demet.sengul.52@gmail.com

How to cite this article. Ozturk T, Sengul D, Sengul I. Jod-Basedow phenomenon: phenomenal thyrotoxicosis? Sanamed.2021;16(3): 221-226 